\title{
Monitoring During Transport
}

\author{
Richard D Branson and Dario Rodriquez Jr
}

\author{
Introduction \\ Guidelines for Transport \\ Adverse Events as a Guide to Required Monitoring \\ Adverse Events During Intrahospital Transport \\ Adverse Events During Interhospital Transport \\ Capnography During Transport \\ Transcutaneous $\mathrm{CO}_{2}$ Monitoring During Transport \\ Early Warning Systems \\ Checklists \\ Summary
}

\begin{abstract}
Transport of critically ill patients within and between hospitals is a common undertaking in an effort to improve patient outcomes. Intrahospital transports are frequently conducted to aid in diagnosis through advanced imaging techniques or to allow image-guided procedures. Interhospital transport is most frequently conducted to bring patients to specialized care, including centers of excellence for cardiac, trauma, transplant, and respiratory failure. Transport outside the hospital can be accomplished by ground or air, the latter including fixed-wing and rotor-wing aircraft. Often overlooked, transport of patients from the scene of an accident or illness to the hospital by emergency medical services is less sophisticated but more common than the other methods combined. Patients are also routinely transported to and from the operating room, a form of transport not commonly studied. Risks are inherent to transport, and an analysis of risks and benefits must be part of any risk-mitigation strategy. Monitoring the patient during transport by attendants and equipment is a key component of risk mitigation. Quicker transport times and specialized transport teams are associated with improved outcomes, whereas severity of illness is a harbinger of untoward complications. The type of monitoring during transport varies widely with the environment, the skill of the attendants, and the severity of patient illness. Standards for patient monitoring during transport are available, but they are predominantly based on expert opinion. This paper reviews guidelines and the risks of transport as a template for required monitoring, and it discusses common mishaps associated with transport and how these can be avoided with appropriate monitoring. Key words: transport; monitoring; capnography. [Respir Care 2020;65(6):882-893. (C) 2020 Daedalus Enterprises]
\end{abstract}

\section{Introduction}

Transport of critically ill patients within and between hospitals is a common undertaking. A considerable amount of research has been devoted to the risks of transport, in particular the risk of moving a mechanically ventilated patient. ${ }^{1-4}$ This includes the purported advantages of using a ventilator versus manual ventilation, ${ }^{5}$ as well as the characteristics of ventilators used. ${ }^{6-9}$ There are, of course, risks associated with patient transport, but the benefits of diagnostic information, intervention, or transfer to specialized care are often worth the risk. ${ }^{10-12}$

Medical transport is a process that involves a wide range of patients and environments. Although the focus is often on the mechanically ventilated patient, a range of patients are subject to transport, from patients receiving only 


\section{MONITORING DURING TransPorT}

oxygen and intravenous fluids to patients on extracorporeal membrane oxygenation. Aeromedical transport carries additional complexities, including hypobarism and the associated hypoxic atmosphere as well as environmental changes (eg, low humidity, low light, vibration, reduced ambient temperature) and resource constraints. Monitoring of a patient during transport is then defined by the patient's severity of illness, availability of equipment, and the environment. This wide disparity within the transport community likely explains the paucity of guidelines and standards.

The purpose of this paper is to review evidence-based recommendations and guidelines for monitoring patients during transport, to identify the need for types of monitoring by reviewing common adverse events, and to propose areas for future research.

\section{Guidelines for Transport}

Despite the frequency of inter- and intrahospital transport, there are only a small number of guidelines relevant to a wide patient population. ${ }^{13-15}$ Specific guidelines for disease states (eg, head injury, stroke, myocardial infarction) are available, but this review focuses primarily on the transport of patients with respiratory failure. The available guidelines are mostly over a decade old and likely require revision.

The American College of Critical Care Medicine (ACCM) guidelines were last updated in 2004. Expert opinion and research published from 1986 through 2001 were used to construct these guidelines. The ACCM's approach was based on the following framework: (1) pretransport coordination and communication; (2) personnel; (3) equipment; (4) monitoring; and (5) documentation. The main emphasis was patient safety through careful preparation, appropriate personnel, and required technology. ${ }^{13}$

The ACCM guidelines include alphabetical lists of recommended transport equipment (65 items) and transport medications (39 items). Devices for monitoring include pulse oximeter, capnograph, noninvasive blood pressure monitor, electrocardiogram (ECG) monitor with vascular pressure monitoring capabilities, and a stethoscope. Of note, the list

\footnotetext{
Mr Branson and Mr Rodiquez are affiliated with the Division of Trauma/Critical Care, Department of Surgery, University of Cincinnati, Cincinnati, Ohio. Mr Rodiquez is also affiliated with the Warfighter Medical Optimization Division, Airman Systems Directorate, 711th Human Performance Wing, Wright-Patterson Air Force Base, Ohio.

A version of this paper was presented at the RESPIRATORY CARE Journal Conference, held June 10-11, 2019, in St. Petersburg, Florida.

Correspondence: Richard D Branson MSc RRT, University of Cincinnati 231 Albert Sabin Way \#0558 Cincinnati, OH 45267. E-mail: branson@aarc.org.
}

DOI: $10.4187 /$ respcare. 07796 specifies end-tidal $\mathrm{CO}_{2}$ monitors, which could include colorimetric devices. Monitoring is implied to be continuous with the exception of noninvasive blood pressure.

The Australian and New Zealand College of Anaesthetists (ANZCA) published guidelines for transport in 2015. ${ }^{14}$ This group's guidelines encompass recommendations for prehospital, interhospital, and intrahospital transport. The ANZCA's list of monitoring equipment includes pulse oximeter, ECG monitor, capnograph, temperature monitor, vascular pressure monitor, and a blood pressure cuff. Proposed monitoring includes routinely assessing the patient's breathing frequency, $\mathrm{S}_{\mathrm{pO} 2}$, capnography (for both ventilated and sedated patients), continuous ECG, blood pressure, and in select circumstances point-of-care arterial blood gas analysis.

The ANZCA guidelines note some caveats regarding monitoring: "Monitoring of certain physiological variables should be carried out during transport. Some or all of these basic recommendations will need to be exceeded routinely depending on the physical status of the patient. Clearly any monitoring method may fail to detect unfavourable clinical developments, and monitoring does not guarantee any specific patient outcome." ${ }^{14}$ This is a cogent reminder that, despite best practice and technology, careful eyes-on monitoring by personnel remains critical.

The AARC guidelines specifically address the mechanically ventilated patient during transport. The list of recommended monitoring activities includes integral monitoring of pressure, checking volume and flow values from the portable ventilator, pulse oximetry, ECG, monitoring vascular pressure, and use of a stethoscope and a hand-held spirometer. The spirometer was recommended to verify ventilator volumes or record spontaneous breathing. Recommended routine monitoring includes continuous ECG monitoring, continuous or intermittent blood pressure monitoring, intermittent recording of breathing frequency, continuous monitoring of airway pressure and volume, intermittent breath sounds, and $\mathrm{S}_{\mathrm{pO} 2}$. A comparison of these guidelines is shown in Table 1.

Guidelines for transport are forced to cover such a wide-ranging class of patients and environments that it is difficult to create a document to cover every eventuality. Monitoring standards are based on expert opinion and common-sense application. Transport without pulse oximetry might seem unthinkable, yet nothing in the literature points to improved outcomes from monitoring $\mathrm{S}_{\mathrm{pO} 2}$. It is interesting that the AARC guidelines do not include capnography, which may be due to the time of the writing (2003) and the cost and size of capnography devices of that time. Capnography may play an important role in monitoring spontaneously breathing patients as a method to detect apnea and in ventilated patients to assure adequacy of ventilation and airway position. Current guidelines require updating. 
Table 1. A Comparison of Monitoring Recommendations From Published Guidelines

\begin{tabular}{|c|c|c|c|}
\hline Organization & $\begin{array}{l}\text { Publication } \\
\text { Date }\end{array}$ & Monitoring Equipment & $\begin{array}{c}\text { Physiologic Variables To Be } \\
\text { Monitored }\end{array}$ \\
\hline $\begin{array}{l}\text { American College of Critical Care } \\
\text { Medicine }\end{array}$ & 2004 & $\begin{array}{l}\text { Pulse oximeter } \\
\text { Capnograph } \\
\text { Noninvasive blood pressure monitor } \\
\text { Electrocardiogram monitor } \\
\text { Vascular pressure monitor } \\
\text { Stethoscope }\end{array}$ & $\begin{array}{l}\text { Heart rate and rhythm } \\
\text { Blood pressure } \\
\text { Breathing frequency } \\
\text { End-tidal } \mathrm{CO}_{2} \\
\text { Breath sounds } \\
\mathrm{S}_{\mathrm{pO} 2}\end{array}$ \\
\hline $\begin{array}{l}\text { Australian New Zealand College of } \\
\text { Anaesthetists }\end{array}$ & 2015 & $\begin{array}{l}\text { Pulse oximeter } \\
\text { Electrocardiogram monitor } \\
\text { Vascular pressure monitor } \\
\text { Stethoscope } \\
\text { Capnograph } \\
\text { Temperature } \\
\text { POC-ABG (select cases) }\end{array}$ & $\begin{array}{l}\text { Heart rate and rhythm } \\
\text { Blood pressure } \\
\text { Breathing frequency } \\
\text { End-tidal } \mathrm{CO}_{2} \\
\text { Breath sounds } \\
\mathrm{S}_{\mathrm{pO} 2} \\
\text { Arterial pH and blood gases }\end{array}$ \\
\hline $\begin{array}{l}\text { American Association for } \\
\text { Respiratory Care }\end{array}$ & 2002 & $\begin{array}{l}\text { Integral monitoring of pressure, volume, } \\
\quad \text { and flow from portable ventilator } \\
\text { Pulse oximeter } \\
\text { Electrocardiogram monitor } \\
\text { Vascular pressure monitor } \\
\text { Stethoscope } \\
\text { Hand-held spirometer }\end{array}$ & $\begin{array}{l}\text { Heart rate and rhythm } \\
\text { Blood pressure } \\
\text { Respiratory frequency } \\
\text { Airway pressures and volume } \\
\text { Breath sounds } \\
\mathrm{S}_{\mathrm{pO} 2}\end{array}$ \\
\hline
\end{tabular}

\section{Adverse Events as a Guide to Required Monitoring}

Adverse events are frequent during transport due to the stresses of moving a patient and the patient's underlying pathophysiology. However, these physiologic perturbations are often reported in studies of patient movement when the important events to capture are serious adverse events. Mishaps or incidents during transport are often overreported, leading to the concern about the risks of transport. Coupled with the memory bias that allows most clinicians to remember "the catastrophe in radiology," an overestimation of transport risks is likely. Undoubtedly, serious adverse events occur during patient movement, but these should be compared to events commonly observed in stationary patients in the ICU setting. ${ }^{16-19}$ Serious adverse events or critical incidents can often be defined as changes in patient condition that require an intervention (eg, change in ventilator settings, change in vasoactive medications, cardioversion, etc.). A list of common physiologic perturbations (ie, adverse events) compared to serious adverse events during transport are shown in Table 2.

\section{Adverse Events During Intrahospital Transport}

A number of studies in the late 1980s and early 1990s provided a basis for understanding the risks of transport and the frequency of adverse events. ${ }^{16,17,20,21}$ Changes in technology and practice allow this data to be viewed in light of more recent publications. Pertinent studies on adverse events during intrahospital transport are reviewed here.

Fanara et $\mathrm{al}^{1}$ performed a systematic review of intrahospital transport of critically ill subjects based on publications from 1998 to 2009. They identified 8 papers that focused on adverse events, of which 6 were prospective trials and 2 were retrospective trials. ${ }^{1822-28}$ These publications included 35 to 290 subjects, of whom two thirds received mechanical ventilation. The analysis specifically addressed clinical problems including cardiovascular incidents, respiratory incidents, and materiel incidences (eg, staff error or equipment failure). ${ }^{1}$ Importantly, the authors identified global adverse events separately from severe adverse events.

The global adverse event incidence was $>50 \%$ in each of the studies, whereas important incidents occurred in only $0-30 \%$ of transports. Doring et $\mathrm{al}^{23}$ reported severe hypotension in $2 \%$ and hypoxemia in $30 \%$ of neurosurgical subjects. Shirley and Stott $^{27}$ reported a global adverse events rate of $59 \%$ but no cardiovascular or respiratory events. In this trial, equipment failure and human error accounted for the majority of incidents. ${ }^{27}$ In a prospective trial of subjects moved from the emergency department to the ICU, Lovell et $\mathrm{al}^{26}$ reported cardiovascular clinical problems in $31 \%$ of subjects and reported 1 death after cardiac arrest.

Beckmann and colleagues ${ }^{28}$ studied 176 patients transported from the ICU and reported severe hypotension in $3 \%$, cardiac arrest in 3\% and hypoxemia in $11 \%$. As with other trials, the rate of equipment and human failures far 
Table 2. Adverse Events (Physiologic Perturbations) and Serious Adverse Events Observed During Transport

\begin{tabular}{|c|c|c|}
\hline & Adverse Event & Serious Adverse Event \\
\hline \multirow[t]{3}{*}{ Cardiovascular } & Blood pressure change $>20 \%$ & $\begin{array}{l}\text { Severe hypotension (systolic blood pressure }<90 \\
\mathrm{~mm} \mathrm{Hg} \text { or mean arterial pressure }<60 \mathrm{~mm} \mathrm{Hg} \text { ) }\end{array}$ \\
\hline & Heart rate change $>20 \%$ & Heart rate $<40$ or $>120$ beats/min \\
\hline & Cardiac arrhythmia & Myocardial infarction \\
\hline \multirow[t]{8}{*}{ Respiratory } & Decrease in $\mathrm{S}_{\mathrm{pO} 2}>5 \%$ & Hypoxemia $\mathrm{S}_{\mathrm{pO} 2}<88 \%$ for $>5$ min \\
\hline & Increase in peak airway pressure $>35 \mathrm{~cm} \mathrm{H}_{2} \mathrm{O}$ & Severe hypercapnia and respiratory acidosis \\
\hline & Hypocapnia, hypercapnia & Pneumothorax (barotrauma) \\
\hline & Breathing frequency change $>25 \%$ & Unplanned extubation \\
\hline & Bronchospasm & Pulmonary embolus \\
\hline & Decrease in endotracheal tube cuff pressure & Apnea \\
\hline & & Plugged endotracheal tube \\
\hline & & Distal endotracheal tube migration \\
\hline \multirow[t]{2}{*}{ Neurologic } & Increase in intracranial pressure $>20 \%$ & Increase in intracranial pressure $>20 \mathrm{~mm} \mathrm{Hg}$ \\
\hline & Decrease in brain tissue oxygen $>20 \%$ & Decrease in brain tissue oxygen $<20 \mathrm{~mm} \mathrm{Hg}$ \\
\hline \multirow[t]{3}{*}{ Homeostasis } & Change in body temperature $>2^{\circ} \mathrm{C}$ & Profound hypothermia \\
\hline & Change in blood glucose $>20 \%$ & Severe bleeding \\
\hline & & Profound hypoglycemia, hyperglycemia \\
\hline \multirow[t]{3}{*}{ Equipment malfunction or failure } & Battery failure on oximeter, capnograph, or & Ventilator failure \\
\hline & electrocardiogram monitor & Ventilator battery failure \\
\hline & & Intravenous pump failure \\
\hline
\end{tabular}

exceeded physiologic insults. ${ }^{28}$ Damm et $\mathrm{al}^{22}$ prospectively studied 64 ICU subjects transported for diagnostic or therapeutic procedures, reporting an average of 2 incidents per transport. This included 2 cardiac arrests, 11 hypoxemic events, and 19 instances of hypotension. A striking finding in this study was ventilator failure in $21 \%$ of transports, which was categorized as oxygen or battery failure in 10 cases and disconnection from the oxygen source in 7 cases. The paper by Damm et al $^{22}$ is also the first paper to identify patient-ventilator asynchrony as a common problem (26\%) during transport. This may be related to sedation, pain during movement, or the inability of portable ventilators to match the performance ICU ventilators. The authors also observed that patient incidents were more commonly associated with sedated subjects, subjects undergoing diagnostic procedures, and use of a turbine ventilator, with the latter likely being an issue with high gas consumption of ventilators utilizing a bias flow during expiration. ${ }^{22}$ The authors concluded, in disagreement with other studies, that transport of mechanically ventilated critically ill patients, was a high-risk procedure associated with potentially severe complications. ${ }^{22}$

In the remaining 3 trials, ${ }^{18,24,25}$ serious adverse events occurred in $<10 \%$ of cases, with cardiac arrest and hypotension being the most common serious adverse events. Two of these trials involved transport from the emergency department to the ICU, and incidents were $>1$ per transport in all 3 studies. The study by Papson et $\mathrm{al}^{18}$ is the only one to report occurrence of a pneumothorax during movement. Instances of equipment failure ranged from $9 \%$ to $46 \%$, and hypoxemia was uncommon.
A multi-center cohort study from the OUTCOMEREA trial group (12 ICUs in France) evaluated 1,782 mechanically ventilated subjects undergoing 3,006 transports (1-17 per subject). Unique to this trial was the evaluation of not only adverse events during transport, but also posttransport complications. After adjustment for propensity score and confounding factors in the $24 \mathrm{~h}$ prior to transport, transport subjects had a higher risk of complications (odds ratio $1.9,95 \%$ CI 1.7-2.2). The need for intrahospital transport was associated with a longer duration of ICU stay but had no impact on mortality. Reported complications included pneumothorax, atelectasis, ventilator-associated pneumonia (VAP), and electrolyte disturbances. ${ }^{18}$ Of note, the increase in VAP rate within $4 \mathrm{~d}$ of transport is consistent with data reported by Kollef et $\mathrm{al}^{29}$ and Bercault et al. ${ }^{30}$ The etiology for an increased rate of VAP following transport may be secondary to changes in patient position, breaking the ventilator circuit, or changes in endotracheal tube cuff pressures. Monitoring cuff pressure or continuous control of cuff pressure might be useful in preventing this complication.

A recent systematic review specifically addresses adverse events during intrahospital transport of critically ill children. ${ }^{31}$ This review included 24 studies with a total of 4,104 transports. In this group of pediatric subjects, respiratory and airway events were the most common adverse events, and the risk of an adverse event increased as the severity of underlying illness and the degree of respiratory support increased. The authors concluded that use of a ventilator was superior to manual ventilation and that most 
Table 3. Adverse Events Reported During Intrahospital Transport of Pediatric Subjects and Suggested Monitoring To Mitigate These Events

\begin{tabular}{|c|c|c|}
\hline Event Category & Adverse Event & Suggested Monitoring Required for Mitigation \\
\hline Alteration in oxygenation or ventilation & $\begin{array}{l}\text { Hypoxemia or desaturation } \\
\text { Hyperoxia }^{31} \\
\text { Hypocapnea or hypercapnia }^{40,41} \\
\text { Spontaneous respiratory rate change } \\
\text { Respiratory depression, failure, or apnea } \\
\text { Escalation in ventilator settings } \\
\text { Decreased } \mathrm{P}_{\mathrm{aO} 2} / \mathrm{F}_{\mathrm{IO} 2}{ }^{44,36,41,42}\end{array}$ & $\begin{array}{l}\text { Oximeter } \\
\text { Capnograph } \\
\text { Airway pressure, volume, and flow } \\
\text { Impedance plethysmography } \\
\text { Respiratory frequency and pattern monitoring }\end{array}$ \\
\hline Artificial airway events & $\begin{array}{l}\text { Unplanned extubation or re-intubation }{ }^{33,35,41} \\
\text { Endobronchial intubation }^{41} \\
\text { Escalation in suctioning requirements }^{32,34,41,42} \\
\text { Endotracheal tube obstruction }^{36,41,42} \\
\text { Ventilator-associated pneumonia }^{29} \\
\text { Pneumothorax }^{35} \\
\text { Emergent tracheostomy }^{36} \\
\text { Airway activation including bronchospasm and coughing }\end{array}$ & $\begin{array}{l}\text { Capnograph } \\
\text { Airway pressure, volume and flow } \\
\text { Impedance plethysmography } \\
\text { Respiratory frequency and pattern monitoring } \\
\text { Acoustic reflectometry } \\
\text { Endotracheal cuff pressure monitor }\end{array}$ \\
\hline Other & $\begin{array}{l}\text { Native airway obstruction } \\
\text { Respiratory depression and apnea } \\
\text { Aspiration }^{35}\end{array}$ & $\begin{array}{l}\text { Capnograph } \\
\text { Respiratory frequency and pattern monitoring } \\
\text { Impedance plethysmography }\end{array}$ \\
\hline
\end{tabular}

adverse events were preventable and could potentially be mitigated by the use of checklists and redundancy. Table 3 lists the reported respiratory events from 15 studies evaluating pediatric transport. Many of these studies were conducted with mechanically ventilated subjects, but others involved subjects with native airway.

\section{Adverse Events During Interhospital Transport}

Interhospital transport typically involves moving patients between hospitals for specialized or higher echelons of care. ${ }^{3}$ Fan et $\mathrm{al}^{3}$ undertook a systematic review of interhospital transport in 2006. Relying on 5 studies ( $n=245$ subjects) in which two thirds of subjects were transported by air and one third by ground, the authors reported a wide range of adverse event reporting. ${ }^{45-51}$ Only 2 of these studies were prospective, and they included just 25 subjects. In 3 studies, a physician was in attendance for all transports. Only the report by Barillo et $\mathrm{al}^{47}$ identified a common adverse event, respiratory alkalosis (19\% of subjects), in subjects ventilated at altitude using pressure control ventilation. In another study, these authors reported similar rates of respiratory alkalosis during aeromedical evacuation using high-frequency percussive ventilation. ${ }^{52}$ These results can be explained by the use of ventilators that lack altitude compensation and thus deliver a larger volume when used higher altitude. ${ }^{53}$ These results suggest that the presence of point-of-care arterial blood gas analysis could play a role in preventing these adverse effects.

Singh and colleagues ${ }^{54}$ studied the use of mechanical ventilation during interfacility transport and reported that the most common adverse event was new-onset hypotension. In this retrospective study, frequent and repeated sedation was provided in $>70 \%$ of cases and neuromuscular blockade in $22 \%$. Hypotension was transient and was most often associated with administration of sedation. ${ }^{54}$ The same authors performed a retrospective review of landbased interfacility transports occurring over a 5-y time frame. They observed $333(6.5 \%)$ critical adverse events in 5,144 transports, which breaks down to 1 in 15 patient movements. New hypotension was the most frequent adverse event, whereas respiratory events were seen in only $1.3 \%$ of cases. Emergency intubation was performed in 4 instances $(0.08 \%)$, and hypoxemia was observed in 65 cases $(1.3 \%)$.

Hypobarism during aeromedical transport would logically increase the likelihood of hypoxemia during interfacility transfer, ${ }^{55}$ yet studies by Wilcox et $\mathrm{al}^{4}$ and Barnes et $\mathrm{al}^{56}$ did not report hypoxemia in ventilated subjects with respiratory failure. In fact, hyperoxemia is more likely. These results are likely secondary to the use of continuous oximetry and the practice of providing additional oxygen to protect against hypoxemic events. ${ }^{57}$

Several studies from the United States military evacuation of casualties from the conflicts in Iraq and Afghanistan provide some insight into adverse events. ${ }^{58,59}$ These trials included mechanically ventilated subjects in cases of non-battle injuries (20\%) and battle injuries $(60 \%)$. In the latter group, subjects were frequently ventilated at settings that did not comply with the ARDSNet tidal volume and PEEP/F $/ \mathrm{IO}_{2}$ tables. However, the mean difference in tidal volume between groups was $30 \mathrm{~mL}$. 


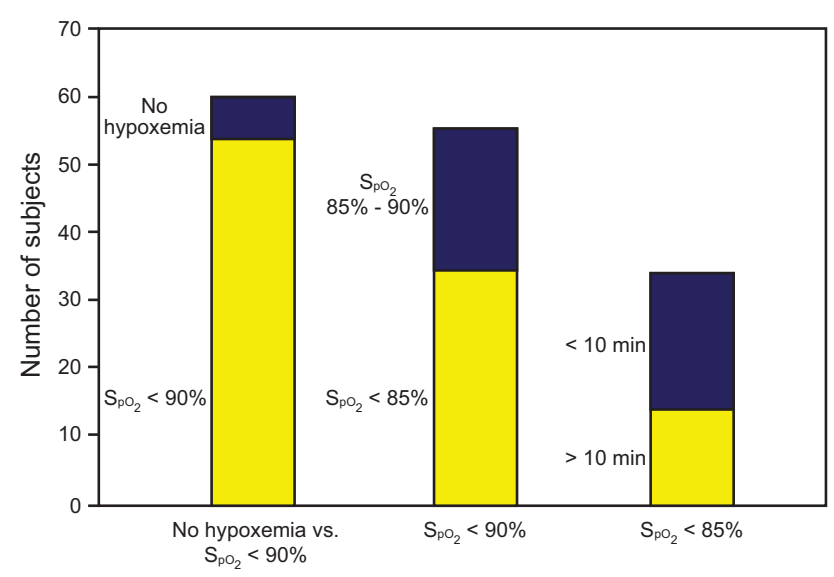

Fig. 1. Incidence of hypoxemia in aeromedical evacuation of casualties not receiving oxygen. The total sample was 61 subjects; only 6 subjects had no events with $\mathrm{S}_{\mathrm{pO} 2}<90 \%$. Of those 55 hypoxemic subjects, 21 subjects had $\mathrm{S}_{\mathrm{pO} 2}$ of $85-90 \%$. The duration of hypoxemia was $<10$ min in 20 subjects and $>10$ min in 14 subjects.

Subjects with noncompliant ventilator settings had more frequent inflight events. The most frequent inflight events were respiratory events, which occurred in $35-43 \%$ of all subjects and in $47 \%$ of subjects ventilated outside the desired settings. These subjects were monitored with pulse oximetry, capnography, ECG, blood pressure, and heart rate, and the mean $\mathrm{S}_{\mathrm{pO} 2}$ was $99 \%$. These data suggest that, even with continuous multimodal monitoring, adverse events are common. Perhaps an early warning system is needed. ${ }^{60}$

In one of the few studies involving subjects who were not mechanically ventilated, our group evaluated $\mathrm{S}_{\mathrm{pO} 2}$ during aeromedical evacuation of the walking wounded. ${ }^{61}$ Our study included 61 subjects who were not receiving supplemental oxygen and could walk (also known as the walking wounded). A mean decrease in $\mathrm{S}_{\mathrm{pO} 2}$ of $4 \%$ was seen in all subjects upon achievement of cruising altitude (ie, barometric pressure of $564 \mathrm{~mm} \mathrm{Hg}$ ). $\mathrm{S}_{\mathrm{pO} 2}<90 \%$ were seen in $90 \%$ (55 of 61) of subjects, and $\mathrm{S}_{\mathrm{pO} 2}<85 \%$ (34 of 61) were seen in $56 \%$ of subjects. The mean duration of hypoxemia at $\mathrm{S}_{\mathrm{pO} 2}<90 \%$ was $>44 \mathrm{~min}$, and the mean duration of hypoxemia at $\mathrm{S}_{\mathrm{pO} 2}<85 \%$ was $12 \mathrm{~min}$. The longest period of hypoxemia at $\mathrm{S}_{\mathrm{pO} 2}<85 \%$ was $44 \mathrm{~min}$. Figure 1 depicts the incidence and duration of hypoxemia. The long-term effects of these hypoxemic events are speculative but could have an impact in patients with head injuries, lung injury, and infections. ${ }^{62,63}$

This review of adverse events during transport demonstrates the frequency and severity of cardiovascular and respiratory compromise seen during transport. Although none of these trials evaluated monitoring, each provides a list of undesirable outcomes, around which monitoring can be designed. Routine use of oximetry, capnography, ECG, blood pressure monitoring, and values provided by the ventilator (eg, airway pressures, volumes, and flows) appear to be required elements for the ventilated patient. In the nonventilated patient, continuous oximetry, heart rate, and breathing frequency seem to be prudent measures. New systems that monitor breathing frequency and volume by acoustics or chest wall movement should be studied. The use of systems that can warn of impending failure should be evaluated. As in many instances, an ounce of prevention is worth a pound of cure.

\section{Capnography During Transport}

Despite the paucity of data on use of monitoring during transport aside from the reports of current practice, capnography has been studied as a method to facilitate ventilation during transport. This includes use in prehospital care and during inter and intrahospital transport. In some of these studies, end-tidal carbon dioxide pressure $\left(\mathrm{P}_{\mathrm{ETCO} 2}\right)$ is used as a target, whereas in others the resultant arterial partial pressure of carbon dioxide $\left(\mathrm{P}_{\mathrm{aCO} 2}\right)$ is reported.

The trauma group from Seattle published a series of papers on $\mathrm{CO}_{2}$ monitoring during prehospital and emergency department ventilation. ${ }^{64-66}$ The first study evaluated intubated trauma patients presenting to the emergency department and receiving mostly manual ventilation. In a retrospective study of almost 600 subjects, the authors reported that hyperventilation and severe hypocapnea was common (18\%). ${ }^{64}$ Hypercapnia was seen in subjects with higher injury severity scores, and these subjects were more likely to be hypoxic and acidodic. Those subjects with normocapnea had better outcomes, particularly in traumatic brain injury. ${ }^{64}$ Their second retrospective study focused on traumatic brain injury, and they reported improved outcomes in subjects with $\mathrm{P}_{\mathrm{aCO} 2}$ being $30-39 \mathrm{~mm} \mathrm{Hg}$ (mortality rate of $21 \%$ vs $33 \%$ ). ${ }^{65}$ Despite the use of the term "targeted $\mathrm{P}_{\mathrm{aCO}}$," the authors reported the resultant $\mathrm{P}_{\mathrm{aCO}}$ during ventilation.

This group's third trial was a prospective observational study comparing $\mathrm{P}_{\mathrm{aCO} 2}$ and $\mathrm{P}_{\mathrm{ETCO} 2}$ in 180 subjects over a 9month observation period. ${ }^{66}$ They reported a poor correlation between the variables, with hypercapnia a common finding when $\mathrm{P}_{\mathrm{ETCO} 2}$ was in the target range of $35-40 \mathrm{~mm}$ $\mathrm{Hg}$. They concluded that $\mathrm{P}_{\mathrm{ETCO} 2}$ should not be used to guide prehospital emergency department ventilatory support. ${ }^{66}$ These findings are important given the relationship between adequate ventilation and outcomes in traumatic brain injury. ${ }^{67}$

Helm et al ${ }^{68}$ evaluated the use of capnography to control prehospital ventilation in trauma subjects. All subjects were monitored with capnography and transported by helicopter, but the capnographic results were only visible to caregivers in half of subjects. ${ }^{68}$ The subjects with $\mathrm{P}_{\mathrm{ETCO} 2}$ monitoring were normocapnic 3 times more often and were less likely to be hypoventilated. ${ }^{68}$ The authors 


\section{MONITORING DURING TransPorT}

concluded that prehospital $\mathrm{P}_{\mathrm{ETCO} 2}$ monitoring was valuable. ${ }^{68}$ As with any discussion of capnography, the impact of cardiac output and dead space must be considered. The relationship of $\mathrm{P}_{\mathrm{aCO} 2}$ and $\mathrm{P}_{\mathrm{ETCO} 2}$ is often widely disparate for reasons unrelated to minute ventilation.

Palmon et al ${ }^{69}$ studied the use of capnography to control manual ventilation during intrahospital transport. Studying 50 subjects moved from the operating room to the ICU, the authors reported no advantage of capnography in these extremely short transport times. ${ }^{69}$ In a small study $(n=12)$ utilizing capnography, Tobias and colleagues ${ }^{40}$ reported that unintentional hyperventilation was common in children during intrahospital transport.

\section{Transcutaneous $\mathrm{CO}_{2}$ Monitoring During Transport}

Transcutaneous monitoring represents another avenue for monitoring ventilation during transport. Maheshwari and Luig ${ }^{70}$ retrospectively reviewed data on 43 neonates during transport, and they reported no benefit of monitoring transcutaneous $\mathrm{CO}_{2}$ to prevent hypocarbia or hypercarbia. Tingay et $\mathrm{al}^{71}$ compared $\mathrm{P}_{\mathrm{ETCO} 2}$ and transcutaneous $\mathrm{CO}_{2}$ during neonatal transport in 21 neonates during transport and concluded that transcutaneous $\mathrm{CO}_{2}$ was preferable to $\mathrm{P}_{\mathrm{ETCO} 2}$ for monitoring ventilation; this study did not address outcomes. Hinkelbein et $\mathrm{al}^{72}$ compared $\mathrm{P}_{\mathrm{aCO} 2}$ to $\mathrm{P}_{\mathrm{ETCO} 2}$ and transcutaneous $\mathrm{CO}_{2}$ during ground transport of critically ill mechanically ventilated adults. Comparing 170 data sets from 34 subjects, the authors concluded that a combination of capnography and point-of-care arterial blood gas analysis might provide the best monitoring. ${ }^{72}$

\section{Early Warning Systems}

The use of early warning systems to predict impending respiratory compromise and need for life-saving interventions has been evaluated by a number of groups. ${ }^{60,73-79}$ The use of the National Early Warning Score, National Early Warning Score 2, Hamilton Early Warning Score, R to R variability on $\mathrm{ECG}, \mathrm{S}_{\mathrm{pO} 2} / \mathrm{F}_{\mathrm{IO} 2}$, and the $\mathrm{ScoreO}_{2}$ have all been described as methods to predict poor outcomes in hospitalized patients. To date, none of these systems have been applied to patients during transport. Given the data in this review, monitoring is prevalent, yet adverse events remain a concern, so the ability to stratify risk on the basis of these scores could prove a fruitful avenue of research.

\section{Checklists}

Two recent papers have highlighted the role of documentation and checklists in safety during transport. ${ }^{80,81}$ Although documentation and checklists are within the scope of monitoring, this paper has attempted to review devices for monitoring and those events that monitoring is designed to avoid. Nonetheless, documentation regarding patient transport deserves some mention. In both studies, the use of a checklist or transport tool is described and the impact on safety is reviewed. ${ }^{80,81}$ This includes the provision of adequate staffing, adequate equipment, and monitoring. These systems are intended to improve continuity, mitigate risks, prevent mishaps, and document the process of transport.

\section{Summary}

Monitoring respiratory and cardiac function during transport is routinely done during prehospital, intrahospital, and interhospital transport. Current guidelines provide a framework for required monitoring, but they need to be updated. In the mechanically ventilated patient, oximetry, ECG, blood pressure, capnography, and monitors integral to the ventilator are standards of care. Monitoring the nonintubated patient has been rarely studied during transport and requires urgent study. The use of early warning systems should be explored as methods to reduces adverse events and improve patient outcomes.

\section{REFERENCES}

1. Fanara B, Manzon C, Barbot O, Desmettre T, Capellier G. Recommendations for the intra-hospital transport of critically ill patients. Crit Care 2010;14(3):R87.

2. Ahmed AH, Thongprayoon C, Schenck LA, Malinchoc M, Konvalinová A, Keegan MT, et al. Adverse in-hospital events are associated with increased in-hospital mortality and length of stay in patients with or at risk of acute respiratory distress syndrome. Mayo Clin Proc 2015;90(3):321-328.

3. Fan E, MacDonald RD, Adhikari NK, Scales DC, Wax RS, Stewart TE, Ferguson ND. Outcomes of interfacility critical care adult patient transport: a systematic review. Crit Care 2006;10(1):R6.

4. Wilcox SR, Richards JB, Genthon A, Saia MS, Waden H, Gates JD, et al. Mortality and resource utilization after critical care transport of patients with hypoxemic respiratory failure. J Intensive Care Med 2018;33(3):182-188.

5. Holets SR, Davies JD. Should a portable ventilator be used in all inhospital transports?. Respir Care 2016;61(6):839-853.

6. Chipman DW, Caramez MP, Miyoshi E, Kratohvil JP, Kacmarek RM. Performance comparison of 15 transport ventilators. Respir Care 2007;52(6):740-751.

7. L'Her E, Roy A, Marjanovic N. Bench-test comparison of 26 emergency and transport ventilators. Crit Care 2014;18(5):506.

8. Blakeman TC, Rodriquez D, Dorlac WC, Hanseman DJ, Hattery E, Branson RD. Performance of portable ventilators for mass-casualty care. Prehosp Disaster Med 2011;26(5):330-334.

9. Boussen S, Gainnier M, Michelet P. Evaluation of ventilators used during transport of critically ill patients: a bench study. Respir Care 2013;58(11):1911-1922.

10. Stevenson VW, Haas CF, Wahl WL. Intrahospital transport of the adult mechanically ventilated patient. Respir Care Clin N Am 2002;8 (1):1-35.

11. Branson RD. Intrahospital transport of the critically ill, mechanically ventilated patient. Respir Care 1992;37(7):775-795.

12. Blakeman TC, Branson RD. Inter- and intra-hospital transport of the critically ill. Respir Care 2013;58(6):1008-1023. 


\section{MONITORING DURING TRANSPORT}

13. Warren J, Fromm RE, Orr RA, Rotello LC, Horst HM, American College of Critical Care Medicine. Guidelines for the inter and intrahospital transport of critically ill patients. Crit Care Med 2004;32 (1):256-262.

14. Australasian College of Emergency Medicine, Australian and New Zealand College of Anaesthetists. Joint Faculty of Intensive Care Medicine. Minimum Standards for Intrahospital Transport of Critically Ill Patients. Available at: http://www.anzca.edu.au/documents/ps522015-guidelines-for-transport-of-critically-ill. Accessed Feb 14, 2020.

15. AARC Clinical Practice Guideline. In hospital transport of the mechanically ventilated patient -2002 revision \& update. Respir Care 2002;47(6):721-723

16. Waydhas C. Intrahospital transport of critically ill patients. Crit Care 1999;3(5):R83-89.

17. Hurst JM, Davis K, Johnson DJ, Branson RD, Campbell RS, Branson PS. Cost and complications during in-hospital transport of critically ill patients: a prospective cohort study. J Trauma 1992;33(4):582-585.

18. Papson JNP, Russell KL, Taylor DM. Unexpected events during the intrahospital transport of critically ill patients. Acad Emerg Med 2007; 14(6):574-577.

19. Schwebel C, Clec'h C, Magne S, Minet C, Garrouste-Orgeas M, Bonadona A, et al. Safety of intrahospital transport in ventilated critically ill patients: a multicenter cohort study. Crit Care Med 2013;41 (8):1919-1928.

20. Braman SS, Dunn SM, Amico CA, Millman RP. Complications of intrahospital transport in critically ill patients. Ann Intern Med 1987;107(4):469-473.

21. Gervais HW, Eberle B, Konietzke D, Hennes HJ, Dick W. Comparison of blood gases of ventilated patients during transport. Crit Care Med 1987;15(8):761-763.

22. Damm C, Vandelet P, Petit J, Richard JC, Veber B, Bonmarchand G, Dureuil B. [Complications during the intrahospital transport in critically ill patients]. Ann Fr Anesth Reanim 2005;24(1):24-30.

23. Doring BL, Kerr ME, Lovasik DA, Thayer T. Factors that contribute to complications during intrahospital transport of the critically ill. J Neurosci Nurs 1999;31(2):80-86.

24. Gillman L, Leslie G, Williams T, Fawcett K, Bell R, McGibbon V. Adverse events experienced while transferring the critically ill patient from the emergency department to the intensive care unit. Emerg Med J 2006;23(11):858-861.

25. Lahner D, Nikolic A, Marhofer P, Koinig H, Germann P, Weinstabl C, Krenn CG. Incidence of complications in intrahospital transport of critically ill patients: experience in an Austrian university hospital. Wien Klin Wochenschr 2007;119(13-14):412-416.

26. Lovell MA, Mudaliar MY, Klineberg PL. Intrahospital transport of critically ill patients: complications and difficulties. Anaesth Intensive Care 2001;29(4):400-405.

27. Shirley PJ, Stott SA. Intrahospital transport of critically ill patients. Anaesth Intensive Care 2001;29(6):669.

28. Beckmann U, Gillies DM, Berenholtz SM, Wu AW, Pronovost P. Incidents relating to the intrahospital transport of critically ill patients. An analysis of the reports submitted to the Australian Incident Monitoring Study in Intensive Care. Intensive Care Med 2004;30 (8):1579-1585

29. Kollef MH, Shapiro SD, Von Harz B, Prentice D, John RS, Silver P, Trovillion E. Patient transport from intensive care increases the risk of developing ventilator-associated pneumonia. Chest 1997;112(3):765773.

30. Bercault N, Wolf M, Runge I, Fleury JC, Boulain T. Intrahospital transport of critically ill ventilated patients: a risk factor for ventilatorassociated pneumonia-a matched cohort study. Crit Care Med 2005;33 (11):2471-2478
31. Haydar B, Baetzel A, Elliott A, MacEachern M, Kamal A, Christensen R. Adverse events during intrahospital transport of critically ill children: a systematic review. Anesth Analg 2019 [Epub ahead of print].

32. Agrawal S, Hulme SL, Hayward R, Brierley J. A portable CT scanner in the pediatric intensive care unit decreases transfer-associated adverse events and staff disruption. Eur J Trauma Emerg Surg 2010;36(4):346-352.

33. Bastug O, Gunes T, Korkmaz L, Elmali F, Kucuk F, Adnan Ozturk M, Kurtoglu S. An evaluation of intra-hospital transport outcomes from tertiary neonatal intensive care unit. J Matern Fetal Neonatal Med 2016;29(12):1993-1998

34. Benavente-Fernández I, Lubián-López PS, Zuazo-Ojeda MA, Jiménez-Gómez G, Lechuga-Sancho AM. Safety of magnetic resonance imaging in preterm infants. Acta Paediatr 2010;99(6):850-853.

35. Harish MM, Siddiqui SS, Prabu NR, Chaudhari HK, Divatia JV, Kulkarni AP. Benefits of and untoward events during intrahospital transport of pediatric intensive care unit patients. Indian J Crit Care Med 2017;21(1):46-48.

36. Nakayama DK, Lester SS, Rich DR, Weidner BC, Glenn JB, Shaker IJ. Quality improvement and patient care checklists in intrahospital transfers involving pediatric surgery patients. J Pediatr Surg 2012;47 (1):112-118.

37. Patel R, Norden J, Hannallah RS. Oxygen administration prevents hypoxemia during post-anesthetic transport in children. Anesthesiology 1988;69(4):616-618.

38. Pullerits J, Burrows FA, Roy WL. Arterial desaturation in healthy children during transfer to the recovery room. Can J Anaesth 1987;34 (5):470-473

39. Ramirez R, Ong J, Peralta L. Assessment of intrahospital transport of critically ill pediatric patients at the University of Santo Tomas Hospital. J Med 2004;52(1):43-47.

40. Tobias JD, Lynch A, Garrett J. Alterations of end-tidal carbon dioxide during the intrahospital transport of children. Pediatr Emerg Care 1996;12(4):249-251.

41. Vieira AL, dos Santos AM, Okuyama MK, Miyoshi MH, de Almeida MF, Guinsburg R. Factors associated with clinical complications during intra-hospital transports in a neonatal unit in Brazil. J Trop Pediatr 2011;57(5):368-374.

42. Wallen E, Venkataraman ST, Grosso MJ, Kiene K, Orr RA. Intrahospital transport of critically ill pediatric patients. Crit Care Med 1995;23(9): 1588-1595.

43. Yeager SB, Horbar JD, Greco KM, Duff J, Thiagarajan RR, Laussen PC. Pretransport and posttransport characteristics and outcomes of neonates who were admitted to a cardiac intensive care unit. Pediatrics 2006;118(3):1070-1077.

44. Marx G, Vangerow B, Hecker H, Leuwer M, Jankowski M, Piepenbrock S, Rueckoldt H. Predictors of respiratory function deterioration after transfer of critically ill patients. Intensive Care Med 1998;24(11):1157-1162.

45. Singh JM, Ferguson ND, MacDonald RD, Stewart TE, Schull MJ. Ventilation practices and critical events during transport of ventilated patients outside of hospital: a retrospective cohort study. Prehosp Emerg Care 2009;13(3):316-323.

46. Belcha S, Dodoo-Schittko F, Brandstetter S, Brandstetter S, Brandl M, Dittmar M. Quality of interhospital transportation in 431 transport survivor patients suffering from acute respiratory distress syndrome referred to specialist centers. Ann Intensive Care 2018;8:5.

47. Barillo DJ, Dickerson EE, Cioffi WG, Mozingo DW, Pruitt BA Jr: Pressure-controlled ventilation for the long-range aeromedical transport of patients with burns. J Burn Care Rehabil 1997;18(3):200-205.

48. Remond C, Jimeno MT, Dubouloz F. Mesures du CO2 expire en transport extrahospitalier: interets et limites. Jeur 1998;4(3):179-186. 


\section{MONITORING DURING TRANSPORT}

49. Orf J, Thomas SH, Wedel SK. Ventilation rates in intubated head injury patients undergoing helicopter EMS (HEMS) transport. Crit Care Med 2000;28:A208.

50. Uusaro A, Parviainen I, Takala J, Ruokonen E. Safe long-distance interhospital ground transfer of critically ill patients with acute severe unstable respiratory and circulatory failure. Intensive Care Med 2002;28(8):1122-1125.

51. Veldman A, Diefenbach M, Fischer D, Benton A, Bloch R. Long-distance transport of ventilated patients: advantages and limitations of air medical repatriation on commercial airlines. Air Med J 2004;23(2):2428.

52. Barillo DJ, Renz EM, Wright GR, Broger KP, Chung K, Thompson CK, Cancio LC. High-frequency percussive ventilation for intercontinental aeromedical evacuation. Am J Disaster Med 2011;6(6):369378.

53. Blakeman T, Britton T, Rodriquez D Jr, Branson R. Performance of portable ventilators at altitude. J Trauma Acute Care Surg 2014;77(3 Suppl 2):S151-S155.

54. Singh JM, MacDonald RD, Ahghari M. Critical events during land based interfacility transport. Ann Emerg Med 2014;64(1):9-15.

55. Muhm JM, Rock PB, McMullin DL, Jones SP, Lu IL, Eilers KD, et al. Effect of aircraft-cabin altitude on passenger discomfort. N Engl J Med 2007;357(1):18-27.

56. Barnes SA, Branson RD, Beck G, Johannigman JA. En-route care in the air: a snapshot of mechanical ventilation at 37,000 feet. J Trauma 2008;64(8):S129-S135.

57. Schauer SG, Apr MD, Naylor JF, Mould-Millman N-K, Bebarta VS, Becker TE, et al. Incidence of hyperoxia in combat wounded in Iraq and Afghanistan: a potential opportunity for oxygen conservation. Mil Med 2019;184(11-12):661-667.

58. Maddry JK, Arana AA, Savell SC, Reeves LK, Perez CA, Mora AG, Bebarta VS. Critical care air transport team evacuation of medical patients without traumatic injury. Mil Med 2017;182(11):e1874e1880.

59. Maddry JK, Mora AG, Savell SC, Perez CA, Mason PE, Maden JK. Impact of critical care air transport team (CCATT) ventilator management on combat mortality. J Trauma Acute Care Surg 2018;84(1):157164.

60. Viglino D, L'her E, Maltais F, Maignan M, Lellouche F. Evaluation of a new respiratory monitoring tool "Early Warning ScoreO2" for patients admitted at the emergency department with dyspnea. Resuscitation 2020;148(1):59-65.

61. Johannigman J, Gerlach T, Cox D, Juhasz J, Britton T, Elterman J. Hypoxemia during aeromedical evacuation of the walking wounded. J Trauma Acute Care Surg 2015;79(4 Suppl 2):S216-S220.

62. Earnest RE, Sonnier DI, Makley AT, Campion EM, Wenke JC, Bailey $\mathrm{SR}$, et al. Supplemental oxygen attenuates the increase in wound bacterial growth during simulated aeromedical evacuation in goats. J Trauma Acute Care Surg 2012;73(1):80-86.

63. Chesnut R, Aguilera S, Buki A, et al. A management algorithm for adult patients with both brain oxygen and intracranial pressure monitoring: the Seattle International Severe Traumatic Brain Injury Consensus Conference (SIBICC). Intensive Care Med 2020 [Epub ahead of print].

64. Warner KJ, Cuschieri J, Copass MK, Jurkovich GJ, Bulger EM. The impact of prehospital ventilation on outcome after severe traumatic brain injury. J Trauma 2007;62(6):1330-1336.

\section{Discussion}

*Kallstrom: Rich, that was great. One of the things I want to mention is
65. Keir W, Cuschieri J, Compass MK, Jurkovich G, Bulger EM. Emergency department ventilation effects outcome in severe traumatic brain injury. J Trauma 2008;64(2):341-347.

66. Warner KJ, Cuschieri J, Garland B, Carlbom D, Baker D, Copass MK, et al. The utility of early end-tidal capnography in monitoring ventilation status after severe injury. J Trauma 2009;66(1):26-31.

67. Davis DP, Dunford JV, Ochs M, Park K, Hoyt DB. The use of quantitative end-tidal capnometry to avoid inadvertent severe hyperventilation in patients with head injury after paramedic rapid sequence intubation. J Trauma 2004;56(4):808-814

68. Helm M, Schuster R, Hauke J, Lampl L. Tight control of prehospital ventilation by capnography in major trauma victims. $\mathrm{Br} \mathrm{J}$ Anaesth 2003;90(3):327-332.

69. Palmon SC, Liu M, Moore LE, Kirsch JR. Capnography facilitates tight control of ventilation during transport. Crit Care Med 1996;24 (4):608-611.

70. Maheshwari R, Luig M. Review of respiratory management of extremely premature neonates during transport. Air Med J 2014;33 (6):286-291

71. Tingay DG, Stewart MJ, Morley CJ. Monitoring of end tidal carbon dioxide and transcutaneous carbon dioxide during neonatal transport. Arch Dis Child Fetal Neonatal Ed 2005;90(6):F523-F526.

72. Hinkelbein J, Floss F, Denz C, Krieter H. Accuracy and precision of three different methods to determine $\mathrm{PCO} 2$ ( $\mathrm{PaCO} 2$ vs. PETCO2 vs. $\mathrm{PtcCO} 2$ ) during interhospital ground transport of critically ill and ventilated adults. J Trauma 2008;65(1):10-18.

73. Liu NT, Salter MG, Khan MN, Branson RD, Enkhbaatar P, Kramer $\mathrm{GC}$, et al. Closed-loop control of FiO2 rapidly identifies need for rescue ventilation and reduces ARDS severity in a conscious sheep model of burn and smoke inhalation injury. Shock 2017;47(2):200-207.

74. Lellouche F, L'Her E. Usual and advanced monitoring in patients receiving oxygen therapy. Respir Care, in press.

75. Smith MEB, Chiovaro JC, O'Neil M, Kansagara D, Quiñones AR, Freeman M, et al. Early warning system scores for clinical deterioration in hospitalized patients: a systematic review. Ann Am Thorac Soc 2014;11(9):1454-1465.

76. Kivipuro M, Tirkkonen J, Kontula T, Solin J, Kalliomaki J, Pauniaho SL, et al. National Early Warning Score (NEWS) in a Finnish multidisciplinary emergency department and direct vs. late admission to intensive care. Resuscitation 2018;128(1):164-169.

77. Hodgson LE, Dimitrov BD, Congleton J, Venn R, Forni LG, Roderick PJ. A validation of the National Early Warning Score to predict outcome in patients with COPD exacerbation. Thorax 2017;72(1):23-30.

78. Pimentel MAF, Redfern OC, Gerry S, Collins GS, Malycha J, Prytherch D, et al. A comparison of the ability of the National Early Warning Score and the National Early Warning Score 2 to identify patients at risk of in-hospital mortality: a multi-centre database study. Resuscitation 2019;134(1):147-156.

79. Fernando SM, Fox-Robichaud AE, Rochwerg B, Cardinal P, Seely AJE, Perry JJ, et al. Prognostic accuracy of the Hamilton Early Warning Score (HEWS) and the National Early Warning Score 2 (NEWS2) among hospitalized patients assessed by a rapid response team. Crit Care 2019;23(1):60.

80. Williams P, Karuppiah S, Greentree K, Darvall J. A checklist for intrahospital transport of critically ill patients improves compliance with transportation safety guidelines. Aust Crit Care 2020;33(1):20-24.

81. Jarden RJ, Quirke S. Improving safety and documentation in intrahospital transport: development of an intrahospital transport tool for critically ill patients. Intensive Crit Care Nurs 2010;26(2):101-107. about 7 years ago the AARC did an analysis of inter-hospital transports, and we found that a lot of patients had adverse episodes, a lot of which were tied to $\mathrm{O}_{2}$. So we put together a checklist, and it's available on our website, for therapists to customize to their own hospital and department. We 
have a pediatric, a neonatal, and an adult checklist available for those who would like access to them. ${ }^{1}$

Branson: Right, it basically gives you how to calculate how much $\mathrm{O}_{2}$ you need based on the time you're gone and whether it's a certain $\mathrm{O}_{2}$ appliance or a mechanical ventilator.

*Kallstrom: Yes, it has that and other things, too. The pulse oximeter placement - the problem is, as we know, a lot of RTs are not doing transports except for critically sick patients. So it's being left to transporters to do this and we wanted to have a way to assure the safety of the patient.

Branson: I think that over time, at least where I work, the RTs used to always go with the ventilated patients and stay with them. Now they take them and leave and go back to the ICU, and leave the monitoring to the machine, the radiology staff, and a nurse. There just isn't enough staff.

Blanch: I have a question for you regarding capnography during transport. There are a couple of articles saying that end tidal $\mathrm{CO}_{2}$ is important in patients with brain injury. So, end tidal $\mathrm{CO}_{2}$ is recommended to avoid high or low levels because these are independently associated with ICU mortality. What's your opinion?

Branson: But most of those are, I think, prehospital.

Blanch: Prehospital transport, right.

Branson: The issue becomes the problem of capnography, if you have a patient with a head injury and also chest trauma at the scene with multiple rib fractures, the end-tidal $\mathrm{PCO}_{2}$ and $\mathrm{P}_{\mathrm{aCO}}$ difference may be quite wide. The head injury patient with an isolated head injury, may have very similar end tidal $\mathrm{P}_{\mathrm{CO}_{2}}$ and arterial $\mathrm{P}_{\mathrm{CO}_{2}}$.
Those 3 papers I showed you ${ }^{2-4}$ using both end tidal and transcutaneous $\mathrm{P}_{\mathrm{CO}_{2}}$ were all transport studies- some were in neonates but the others were looking at tighter control of end tidal $\mathrm{P}_{\mathrm{CO}_{2}}$, particularly in brain-injured patients. I think it's important, but to my knowledge at my hospital I've never seen a mechanically ventilated patient leave the ICU with capnography. And maybe they ought to.

Blanch: I was referring from the field to the emergency department, even before the ICU. The time when they transport the patient either by ambulance or air.

Branson: I think that's important as well, but I don't think that gets done very often. The work by the group from Seattle has shown an association between end tidal $\mathrm{P}_{\mathrm{CO}_{2}}$ and $\mathrm{P}_{\mathrm{aCO}_{2}}$ They find a poor correlation between the two measures which is worsened by poor tissue perfusion. The relationship was closest in subjects with isolated head injury. They report that patients with an end-tidal $\mathrm{P}_{\mathrm{CO}_{2}}$ of 35 $40 \mathrm{~mm} \mathrm{Hg}$ were under-ventilated $80 \%$ of the time with a $\mathrm{P}_{\mathrm{aCO}}$ of $>50 \mathrm{~mm}$ $\mathrm{Hg}$ in one third of cases. They suggest not using end tidal $\mathrm{P}_{\mathrm{CO}_{2}}$ as a guide for prehospital ventilation. ${ }^{5}$

Pham: Are you aware of studies comparing the safety of transport between different types of professionals, like RTs and trainees? One of the things I noticed when I arrived in Toronto, and I suppose it's the same in North America, was people being transported by nurses and RTs for mechanical ventilation. Whereas back in France where I was trained, ICU patients were transported by physicians, either residents or trainees depending on how it was staffed. And I know that for new trainees sometimes it was very challenging and they were not aware of what were the important things to monitor during transport and you would have some accidents or places for improvement in training or simulations. At least in Europe, but I don't know how is the training done for people here who are experts in transport?

Branson: I think there are different models. At my university, we still send a physician in the helicopter out to the field, which in North America is fairly rare. There are a lot of studies that I didn't show that look at the use of critical care paramedics to improve safety in transport, some of those are in the hospital and some are outside the hospital. But these studies are trying to address the issue of reduced RT and nursing staff availability to go on transport with these patients. To my knowledge, no studies have ever shown that having a physician on transport, or having a nurse, or having an RT, or not having one of those people changes the outcome for the patient. It makes sense - we have a ground transport group who are paramedics who often come and get the patients who are going to transported to our long-term mechanical ventilation facility and they show up with a very simple portable ventilator and standard circuit and no humidifier, not even an HME. And often they will pick up a patient who's been in the ICU for 2-3 weeks who's been very sick and has thick secretions and they're going to ventilate them with no humidity for however long it takes them get set up on the ventilator, transferred down to the emergency department, loaded in the ambulance, and driven up the interstate. It might be several hours. As much as I've tried to coach them about that, it's just not on their radar as something that's important. Regardless of who is part of the team - we have to make sure they have the requisite training.

Scott: I did want to ask you more about equipment during transport. Did you say battery failure was a major issue to consider during transport? 
Branson: In terms of equipment, battery failure is the most common.

Scott: Does that mean immediate loss of power, or is it that the battery is old and doesn't hold charge as much as it should?

Branson: I don't know there's enough granularity to distinguish that. What it means is you left the ICU with a ventilator that had power supply, you left the ICU with a physiologic monitor that was running on battery, and sometime while you were gone the battery charge is gone and now you don't have that device anymore.

Scott: Did you see anything in the literature about $\mathrm{O}_{2}$ tanks running out before you get from point A to point $\mathrm{B}$ ?

Branson: There are a couple but I would suggest that it doesn't get reported very often.

Goligher: I have a question about transport, probably the most difficult transport decision that I am involved in is when we're called on a patient with refractory hypoxemia in the community and we are considering them for ECMO. Often our practice is to try and bring them to our center before cannulation, I don't know if it's something in the air in our ICU but often we find we can stave off the need for ECMO just with optimizing ventilation, proning, etc. But sometimes the patients are a bit marginal and I've had a few cases where we decided to try and transport without cannulating, they get put on the LTV ventilator for transport and they deteriorate substantially on exactly the same settings as they were on in the other ventilator. The constant comment is that the transport ventilator cannot perform at the same level with the same settings. I'm curious to know- from a group of people who really understand the mechanics of delivering ventilation what is it about these transport ventilators that's different? Do they not actually achieve the pressures that are set or what's going on?

Branson: In that case, it depends. Is it the LTV 1000 or 1200 ?

\section{Goligher: I don't know.}

Branson: The LTV is capable of high airway pressures and fast flows, the maximum PEEP is $20 \mathrm{~cm} \mathrm{H}_{2} \mathrm{O}$, the triggering is pretty reasonable. The one area I've seen trouble is in pressure control. The LTV1000 operates like an NIV device. If you set the PEEP at $10 \mathrm{~cm} \mathrm{H}_{2} \mathrm{O}$ and the pressure at $10 \mathrm{~cm} \mathrm{H}_{2} \mathrm{O}$, you actually get nothing, if you want $10 \mathrm{~cm} \mathrm{H}_{2} \mathrm{O}$ of pressure you have to set the pressure at 20 $\mathrm{cm} \mathrm{H}_{2} \mathrm{O}$. I have seen a number of occasions where I get calls, "we brought these patients back to wherever we were going and they were hypercarbic with severe respiratory acidosis' and it was because they didn't appreciate that difference. Other than that, most of the portable ventilators that are available are capable of doing most modes that ICU ventilators can. Although the LTV can't do adaptive pressure ventilation, so if you're using PVRC or something. But if you're doing pressure control it really shouldn't matter.

$\dagger$ Hess: There are 3 issues I think of. One Rich just mentioned. Another is that, although all of our critical care ventilators compensate for the compressible volume in the circuit, I don't know that any of the transport ventilators do. So, the same set tidal volume might be less delivered down the endotracheal tube with a portable ventilator. The third thing is that many of the transport ventilator circuits come with a 6-inch flex tube that adds dead space. There is a reduction in the delivered tidal volume due to compressible volume, and then a further reduction in alveolar ventilation because of the dead space in the circuit. I think those issues, in addition to what Rich said, can result in what you are describing.

Scott: On top of that 6-inch corrugated tube you're talking about, there's an HME attached to it with another $60 \mathrm{~mL}$ of dead space as well.

$\dagger$ Hess: Right. Your patient with refractory hypoxemic respiratory failure is set on a tidal of $300 \mathrm{~mL}$, but now a third of that that is dead space ventilation.

Branson: Ideally you'd use an HME that is $30 \mathrm{~mL}$ or no more than 60 $\mathrm{mL}$. The compressible volume in most circuits these days is about $2 \mathrm{~mL} / \mathrm{cm}$ $\mathrm{H}_{2} \mathrm{O}$. So if you're ventilating a patient at a pressure of 30 you would expect to lose $60 \mathrm{~mL}$ into the compressible volume that's not accounted for, that would be compensated for if you were using an ICU ventilator.

Rackley: If I'm on the phone with the transport critical care team and the providers at the other hospital have no idea what you're talking about here what questions should I be asking, and what should I be thinking about? Should the first response be to increase the tidal volume a bit? The airway pressure measurements should still be valid, so as long as my plateau pressures are not going extremely high, I'm not necessarily going to cause harm by going up on tidal volume by $100 \mathrm{~mL}$, correct? Should that be our first response in a situation like this, or should we consider something else?

Branson: I think the answer is try to make the compensation based on some educated guess. Again, if you're using pressure control instead of volume control the compressible volume issue isn't as important. But still, if you have the HME and then the tubing that connects the HME to the tracheostomy tube or endotracheal tube that's additional dead space the 
patient will rebreathe. In which case you have to increase either the tidal volume or the set pressure in pressure control to achieve the same alveolar ventilation. As we're talking I'm thinking it' $d$ be a useful place for end tidal $\mathrm{CO}_{2}$. Compare end tidal $\mathrm{P}_{\mathrm{CO}_{2}}$ on the ventilator sitting in the hospital and then monitor it when you switch to the transport ventilator and see what happens and if you see that rise you'd suspect it's due to additional dead space.

Schmidt: How much of the hypoxemia might be related to derecruitment, either due to disconnects or postural changes that happen around the time of transport rather than differences in the ventilator per se?

Goligher: It's quite possible with a disconnect, although I think they consistently clamp the tube. We've actually kept the patient in the bed and just switched to the different ventilator because I've had that experience of being worried about it so had them checked on the transport ventilator even before they're moved to the paramedics' trolley. And it still seems to happen sometimes. But great points.

Walsh: One of the things we've studied is that clamping of the tube doesn't really work. We looked at EIT and clamping the endotracheal tube and you still see lung volumes fall. So if you think you're helping you're likely not helping as much as you think you are. Doing another recruitment maneuver after you get them on the ventilator is probably important. Additionally, the LTV specifically measures at the airway so your tidal volume loss should be maintained, in other words you should be able to see if the tidal volume is less than what they were doing on the critical care ventilator. I think your initial question of why is the tidal volume important, because if they switch over and aren't getting the same tidal volume with the same pressure then you are losing alveolar ventilation and you should crank up the pressure to achieve that. I think re-recruitment is really important. I will say from doing transport for many years, we often suction the patient up before we move them so we actually contribute sometimes to derecruitment because we don't want a plugged airway between facilities. It's often easier to handle it in the ICU you're at instead of in the back of a truck. Sometimes you have to stay a little bit longer to recover the derecruitment you created and maybe do some recruitment maneuvers.

Goligher: Does this happen when you don't clamp properly or is it that clamping period doesn't work?

Walsh: As we talked about earlier with cuff pressure, it actually does not seal perfectly. So a lot of times when you do a 40 for 40 or you clamp on a high level of PEEP, you actually still lose airway pressure.

Branson: The group from Ann Arbor, a huge ECMO referral center, have published a paper ${ }^{6}$ where they go to pick up patients who are being referred for ECMO and put them on INO for the transport back to get that bump in $\mathrm{P}_{\mathrm{aO}}$ and then bring them back to hospital safely.

Goligher: I guess it's quite literally something in the air that makes a difference.

Blanch: Modern transport ventilators have excellent communication protocols, so you can track the patient while waiting for it.

\section{REFERENCES}

1. American Association for Respiratory Care. Patient safety checklists. http://www.aarc. org/resources/clinical-resources/patientsafety-checklist/ Accessed 8/23/19.

2. Helm M, Schuster R, Hauke J, Lampl L. Tight control of prehospital ventilation by capnography in major trauma victims. $\mathrm{Br} \mathrm{J}$ Anaesth 2003;90(3):327-332.

3. Maheshwari R, Luig M. Review of respiratory management of extremely premature neonates during transport. Air Med J 2014; 33(6):286-291

4. Tingay DG, Stewart C, Morley CJ. Monitoring of end tidal carbon dioxide and transcutaneous carbon dioxide during neonatal transport. Arch Bis Child Fetal Neonatal Ed 2005;90:F523-F526.

5. Warner KJ, Cuschieri J, Garland B, Carlbom D, Baker D, Copass MK, et al. The utility of early end-tidal capnography in monitoring ventilation status after severe injury. J Trauma 2009;66(1):26-31.

6. Teman NR, Thomas J, Bryner BS, Haas CF, Haft JW, Park PK, et al. Inhaled nitric oxide to improve oxygenation for safe critical care transport of adults with severe hypoxemia. Am J Crit Care 2015;24(2): 110-117.

\footnotetext{
* Thomas J Kallstrom MBA RRT FAARC is Chief Executive Officer of the AARC.

$\dagger$ Dean R Hess PhD RRT FAARC is Managing Editor of RESPIRATORY CARE.
} 